\title{
Impact of decreasing water demand on bank filtration in Saxony, Germany
}

\author{
T. Grischek, D. Schoenheinz, C. Syhre, and K. Saupe \\ University of Applied Sciences, Faculty of Civil Engineering/Architecture, Division of Water Sciences, \\ Friedrich-List-Platz 1, 01069 Dresden, Germany
}

Received: 15 July 2009 - Published in Drink. Water Eng. Sci. Discuss.: 27 August 2009

Revised: 30 November 2009 - Accepted: 14 January 2010 - Published: 29 January 2010

\begin{abstract}
Bank filtration has been of great importance to the drinking water supply in Germany for many decades. The water quality of pumped raw water from bank filtration sites depends to a high degree on the water quality of the infiltrating surface water and the landside groundwater, the mixed portion of both, as well as the flow and transport conditions in the aquifer. Following the improvement of river water quality and a drastic decrease in water demand during the last 20 years in Germany, the influence of landside groundwater quality has become more important for the raw water quality of waterworks relying on bank filtration. The hydrogeologic analysis of three bank filtration sites in Saxony and the management of abstraction rates and well operation in response to fluctuating water demand are discussed.
\end{abstract}

\section{Bank filtration in Germany}

In Germany, only 3\% of the annually available water resources are needed for the public water supply. In 2007, the main sources were groundwater and spring water (70\%), followed by surface water and artificial infiltrate (22\%), and bank filtrate (8\%) (FSA, 2009).

In place of direct surface water abstraction, bank filtration with subsequent natural aquifer treatment has been used for water supply purposes since the 1870s. Two of the oldest exploited bank filtration sites are the Düsseldorf-Flehe Waterworks on the River Rhine and the Dresden-Saloppe Waterworks on the River Elbe. Both have been providing daily drinking water for several hundred thousand people since 1870 and 1875 , respectively.

The water abstraction relies mostly on vertical wells, except for the waterworks along the River Rhine where horizontal wells are also installed. Typical characteristics for bank filtration sites in Germany are given in Table 1.

Abstracted raw water is a mixture of bank filtrate and landside groundwater. Thus, raw water quality does not only depend on river water quality but also on landside groundwater quality. Due to the intensive agricultural use of the landside catchment, high portions of landside groundwater may result

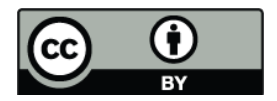

Correspondence to: $\mathrm{T}$. Grischek (grischek@htw-dresden.de) in increased concentrations of nitrate, sulphate, hardness and pesticides.

Poor quality of river water, in combination with high loads of suspended matter, may also result in river bed clogging. While the clogging layer comprises the biologically most active layer, it also strongly reduces water infiltration if the hydraulic conductivity decreases.

\section{Bank filtration in Saxony}

\subsection{Water demand and bank filtrate abstraction}

The Federal State of Saxony is located in the Southeast of Germany, bordered by the Czech Republic to the south and Poland to the east (Fig. 1). Bank filtrate as a raw water source is used for both drinking water supply and process water. Bank filtration sites are concentrated in the lower lands at the rivers Mulde and Elbe and their tributaries, but also at the Lausitzer Neisse (Fig. 1).

In one study, 19 bank filtration sites for the production of drinking water and 13 bank filtration sites for the production of process water were investigated. The bank filtration characteristics found in Saxony are typical for Germany, though no horizontal wells are operated. The abstraction rates of the waterworks producing drinking water range from $4000 \mathrm{~m}^{3} / \mathrm{a}$ (Koltzschen Waterworks on the River Zwickauer Mulde) to $21650000 \mathrm{~m}^{3} / \mathrm{a}$ (Torgau Waterworks on the River Elbe). Waterworks supplying process water abstract between

Published by Copernicus Publications on behalf of the Delft University of Technology. 


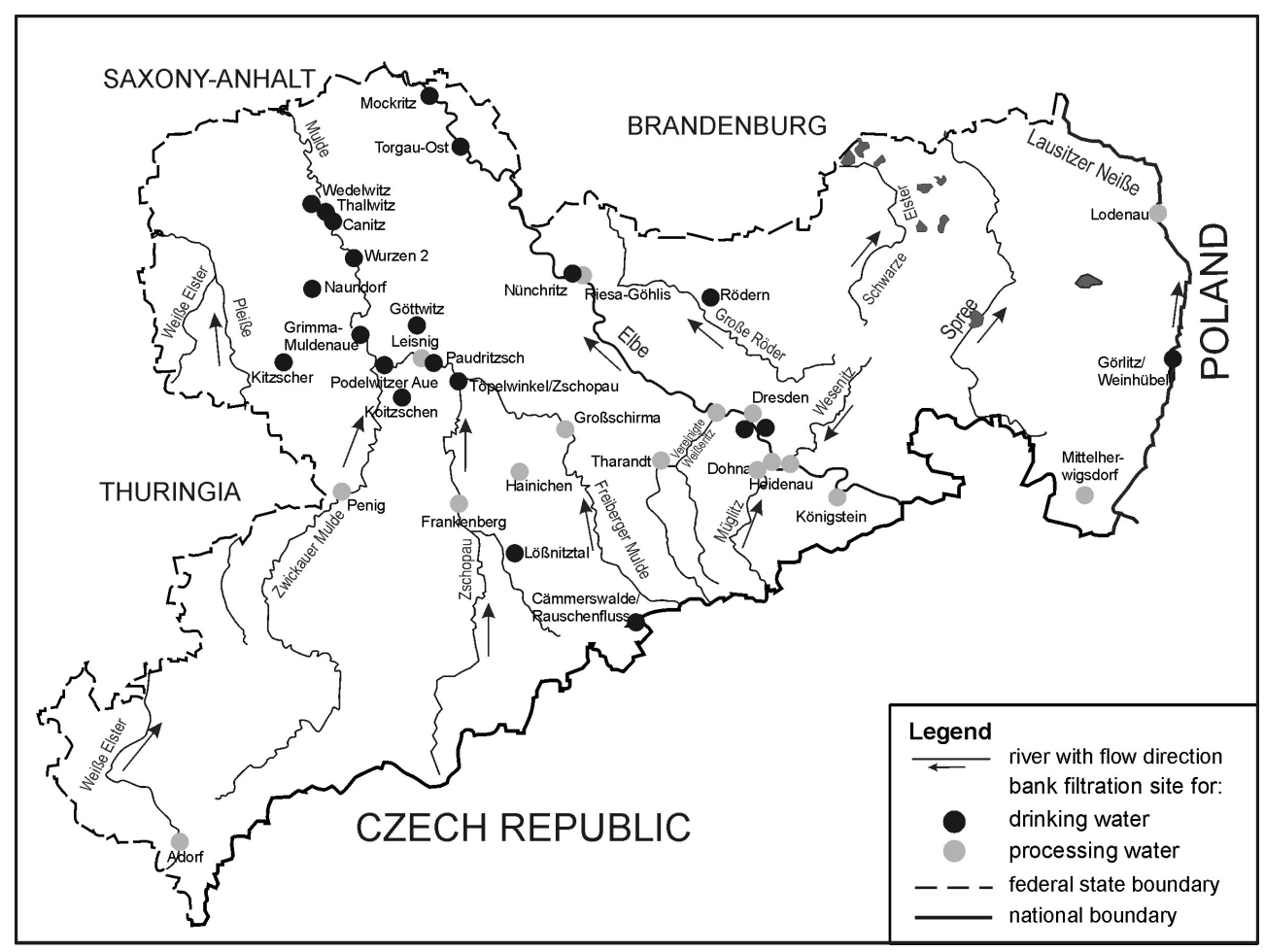

Figure 1. Bank filtration sites in Saxony.

Table 1. Characteristics of bank filtration sites in Germany (Kühn and Müller, 2005).

\begin{tabular}{ll}
\hline Condition & Typical range \\
\hline aquifer thickness & 4 to $70 \mathrm{~m}$ \\
hydraulic conductivity & 0.0001 to $0.05 \mathrm{~m} / \mathrm{s}$ \\
distance bank - well & 20 to $860 \mathrm{~m}$ \\
well fields length along river & 1 to $2 \mathrm{~km}$ \\
travel times & 3 days to 0.5 years \\
\hline
\end{tabular}

$18250 \mathrm{~m}^{3} / \mathrm{a}$ to $2453000 \mathrm{~m}^{3} / \mathrm{a}$. The portion of bank filtrate accounts for 15 to $96 \%$ of the pumped raw water. For many waterworks used for drinking water production, travel times of bank filtrate have been determined by using groundwater flow modelling, measurements of temperature and electrical conductivity and investigations using chloride and persistent trace organics.

Before 1990, the planning and construction of waterworks and well galleries was based on a predicted water demand of up to 200 litres per capita per day. Since 1990 many waterworks, especially in East Germany, have been facing drastic reductions in water consumption. Mean water abstraction rates for public water supply decreased due to political changes, the "water price shock" after the re-unification of Germany, demographic changes, and changes in con-

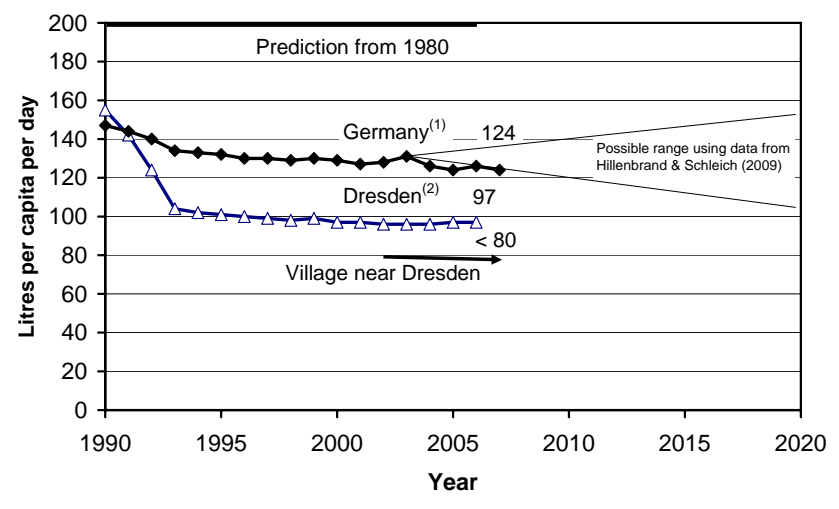

Figure 2. Development of water demand per capita per day in Germany and Saxony. (1) BDEW (2009); (2) City of Dresden (2009).

sumption patterns (Fig. 2). While in Saxony in 1991 the production of raw water from bank filtrate totalled about $40 \times 10^{6} \mathrm{~m}^{3} / \mathrm{a}$, since 2001 the abstraction has been only about $20 \times 10^{6} \mathrm{~m}^{3} / \mathrm{a}$. In some regions, water use decreased by more than $50 \%$ within 10 years. Due to the expected demographic development, a further decline in water consumption and thus water production is expected.

At many bank filtration sites, reduced water abstraction results in a lower portion of bank filtrate in the abstracted raw water. Thus, the quality of the landside groundwater becomes more important for the subsequent water treatment. 


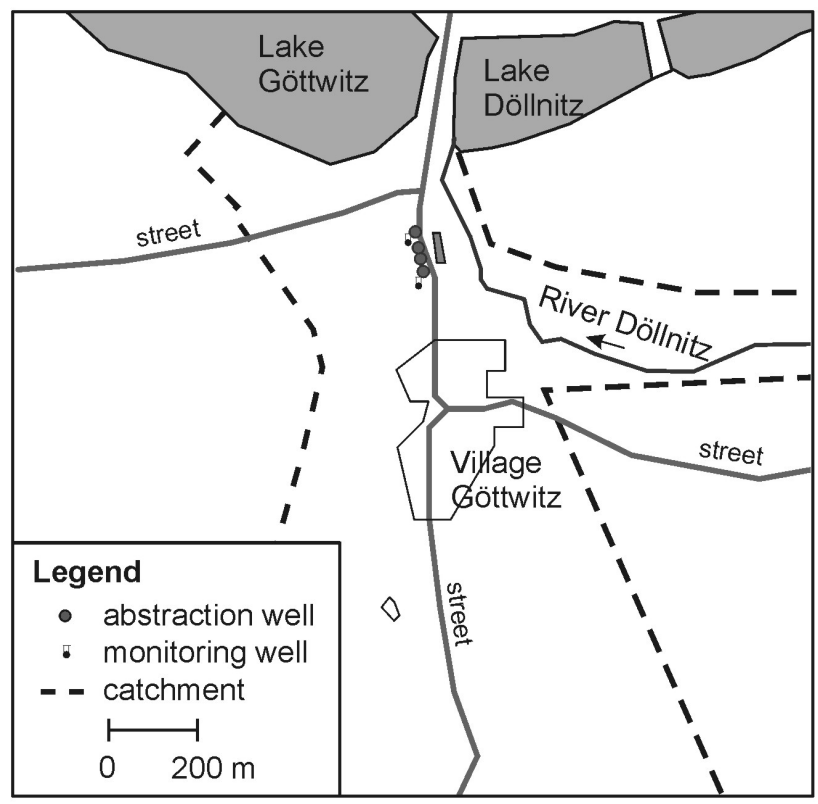

Figure 3. Scheme of the bank filtration site in Göttwitz.

Table 2. Geohydraulic conditions for the Göttwitz site.

\begin{tabular}{ll}
\hline Condition & Average value \\
\hline aquifer thickness & $10 \mathrm{~m}$ \\
hydraulic conductivity & $2 \times 10^{-4} \mathrm{~m} / \mathrm{s}$ \\
distance between lake bank and abstraction wells & $200 \mathrm{~m}$ \\
number of wells & 4 \\
maximum total abstraction rate & $1700 \mathrm{~m}^{3} / \mathrm{d}$ \\
\hline
\end{tabular}

To mitigate this effect, a reduction in the number of wells seems reasonable. However, since peak demands still have to be met, this option is not everywhere practicable.

In the following section, the impact of a reduced mean water abstraction on bank filtrate portions and travel times will be presented for three waterworks in Saxony and a hypothetical RBF site typical of Saxony.

\subsection{Bank filtration site in Göttwitz}

The bank filtration site in Göttwitz is located in the lowlands of northwest Saxony (Fig. 1) close to the Döllnitz stream in the east and Lake Göttwitz in the north (Fig. 3). In accordance with the general discussion, water abstraction decreased between the early 1990s and 2008 from about $1700 \mathrm{~m}^{3} / \mathrm{d}$ to about $1000 \mathrm{~m}^{3} / \mathrm{d}$ due to a lower water demand per capita per day (water savings) and reduction of leakage in the drinking water distribution systems. A sandy aquifer of low thickness (Table 2) is overlain by a mighty clay layer, limiting infiltration from the Döllnitz stream.
Table 3. Geohydraulic conditions for the Görlitz-Weinhübel site.

\begin{tabular}{ll}
\hline Condition & Average value \\
\hline aquifer thickness & $10 \mathrm{~m}$ \\
hydraulic conductivity & $1 \times 10^{-3} \mathrm{~m} / \mathrm{s}$ \\
distance between river bank & 50 to $150 \mathrm{~m}$ \\
and abstraction wells & \\
number of wells & 32 \\
maximum total abstraction rate & $11248 \mathrm{~m}^{3} / \mathrm{d}$
\end{tabular}

For an abstraction rate of $1700 \mathrm{~m}^{3} / \mathrm{d}$, the corresponding bank filtration portion was determined to $13 \%$ based on groundwater flow modelling using Processing Modflow (Schwanke, 2008). The bank filtrate originates both from the Lake Göttwitz (12\%) and the Döllnitz stream (1\%). The low percentage of bank filtrate in the pumped raw water is caused by the morphology of the confining layer of the upper aquifer and management of lake water levels. Lake Göttwitz has a higher water level than Lake Döllnitz, which periodically is emptied.

A reduced water abstraction of about $1000 \mathrm{~m}^{3} / \mathrm{d}$ results in a lower bank filtration portion of about $4 \%$. The travel time between the lake and the northern well was calculated to be longer than 4 months for an abstraction rate of $1700 \mathrm{~m}^{3} / \mathrm{d}$ and longer than 20 months for $1000 \mathrm{~m}^{3} / \mathrm{d}$. The travel time for the infiltrating stream water (1-2\% of abstracted water) has been calculated to be 2-3 months for both scenarios. If the water demand decreases further, the portion of bank filtrate will likewise be reduced, and only groundwater will be abstracted. This may cause problems in the future because nitrate and sulphate concentrations in the groundwater in the nearby agricultural area are high, whereas the nitrate concentration of bank filtrate is very low. Operation of only one well located nearest to the lake bank instead of all four wells would not have a noticeable effect on the bank filtrate portion if the total abstraction is low.

\subsection{Görlitz-Weinhübel Waterworks}

The Görlitz-Weinhübel Waterworks is located in East Saxony, at the German-Polish border, in the floodplain of the River Lausitzer Neisse (Fig. 1). The waterworks supplies drinking water from bank filtrate and artificially recharged groundwater. A lake and several artificial infiltration basins are fed by river water to augment the quantity of available water in the abstraction wells (Fig. 4). This technique was mainly practised during the 1980s, when water demand and consumption were at a relatively high level. However, recent investigations into the infiltration capacity of the lake proved that the bottom of the lake is almost completely clogged.

The main hydrogeological and technical information for the site is given in Table 3 . 


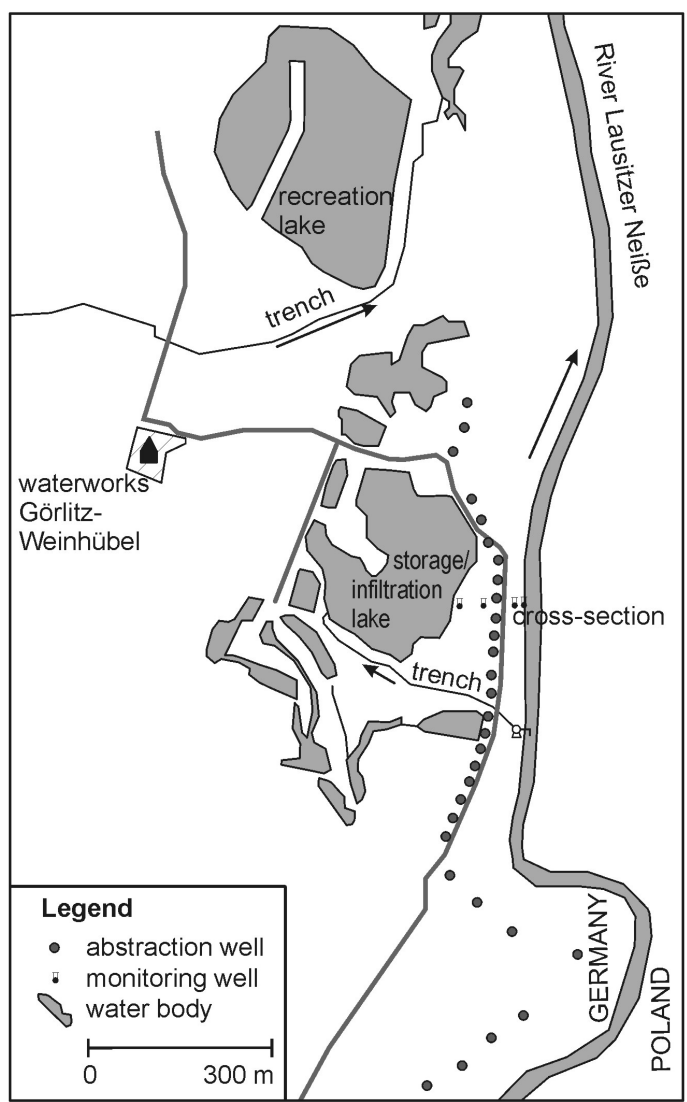

Figure 4. Scheme of the bank filtration site in Görlitz-Weinhübel.

The shortest travel occurs between the river and the well north of the cross-section (Fig. 4). Based on an analysis of seasonal temperature data for river water and groundwater as well as hydraulic gradients the travel time of bank filtrate was determined to be 8 to 24 days depending on river stage. Lower abstraction from the siphon pipe system results in a longer travel time. Originally, the impact of landside water quality was low, because river water would infiltrate in the lakes and basins. However, due to significant clogging of the lake bed, the portion of landside groundwater abstracted is expected to increase. This would result in higher manganese (greater than $1 \mathrm{mg} / \mathrm{L}$ ) and ammonia concentrations (greater than $0.5 \mathrm{mg} / \mathrm{L}$ ) in the pumped raw water.

\subsection{Meissen-Siebeneichen Waterworks}

The river bank filtration site in Meissen-Siebeneichen is situated on the River Elbe, in a transverse valley between the Spaar Mountains and the Meissen granite bedrock (Fig. 5). The valley is filled with Pleistocene deposits to a depth of 5-20 m that comprise interfingered glaciofluviatile sediments ranging from fine sand to medium sand and gravel. The deposits are overlain by Holocene meadow loam (2-7 m

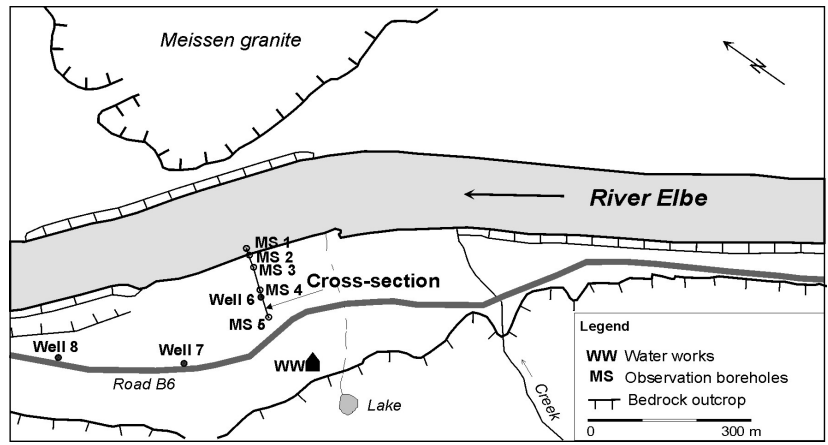

Figure 5. Scheme of the bank filtration site in MeissenSiebeneichen.

Table 4. Geohydraulic conditions for the Meissen-Siebeneichen site.

\begin{tabular}{ll}
\hline Condition & Average value \\
\hline $\begin{array}{l}\text { aquifer thickness } \\
\text { hydraulic conductivity }\end{array}$ & $18 \mathrm{~m}$ \\
distance between river bank & 1.2 to $1.4 \times 10^{-3} \mathrm{~m} / \mathrm{s}$ \\
$\begin{array}{l}\text { and abstraction wells } \\
\text { number of wells }\end{array}$ & 3 \\
max. total abstraction rate & $3800 \mathrm{~m}^{3} / \mathrm{d}$ \\
\hline
\end{tabular}

thick). Along the monitored cross-section, the thickness of the aquifer is about $18 \mathrm{~m}$ (Table 4).

The mean discharge of the River Elbe at Meissen is about $300 \mathrm{~m}^{3} / \mathrm{s}$. Groundwater recharge in the $200-300 \mathrm{~m}$ wide strip between the river and the bedrock is very low due to the meadow loam cover. Groundwater flow from faults in the bedrock and from the other side of the river beneath the river bed towards the production wells was assumed to be negligible. Thus, the only source of the pumped raw water was thought to be river water via bank filtration.

Groundwater samples were taken from the cross-section at a quarterly interval in 1993-1995 and on 12 May 2001 (Fig. 6). Groundwater was obtained using either a mobile submersible pump lowered into $120 \mathrm{~mm}$ diameter observation wells or from in situ membrane pumps used to sample from directly below the bed of the River Elbe. In the field, well head measurements included temperature, $\mathrm{pH}$, alkalinity and $\mathrm{O}_{2}$. In the laboratory, analyses included major ions, iron and manganese. Analyses were carried out according to German guidelines and DIN methods. Prior to analysis, water samples were filtered through a $0.45 \mu \mathrm{m}$ celluloseacetate filter. The concentrations of anions $\mathrm{Cl}^{-}, \mathrm{NO}_{3}^{-}$, and $\mathrm{SO}_{4}^{2-}$ were determined using ion-chromatography.

The results of field investigations between 1993 and 1995 showed very high nitrate (up to $130 \mathrm{mg} / \mathrm{L}$ ), chloride and sulphate concentrations at the bottom of the aquifer between the production well and the River Elbe (Fig. 7a). 


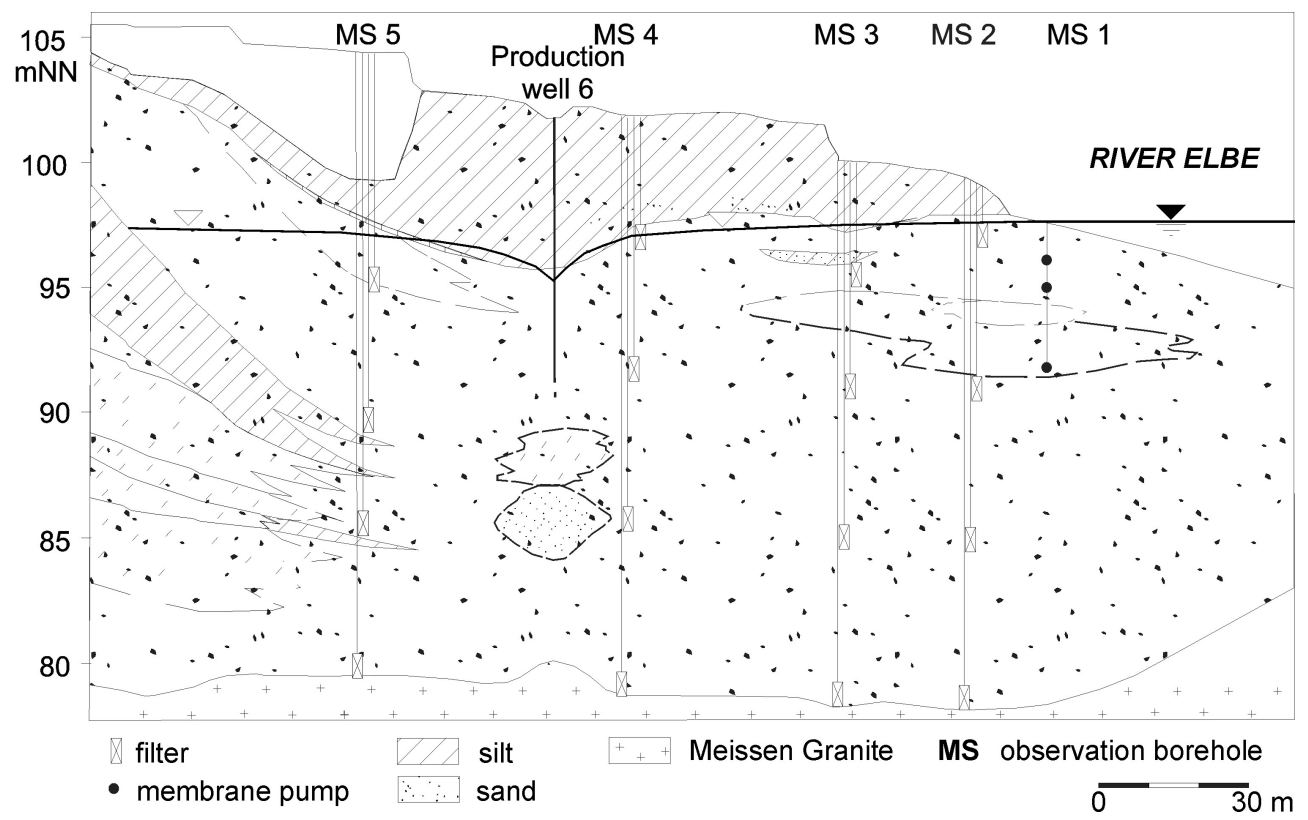

Figure 6. Location of observation boreholes along the cross-section.

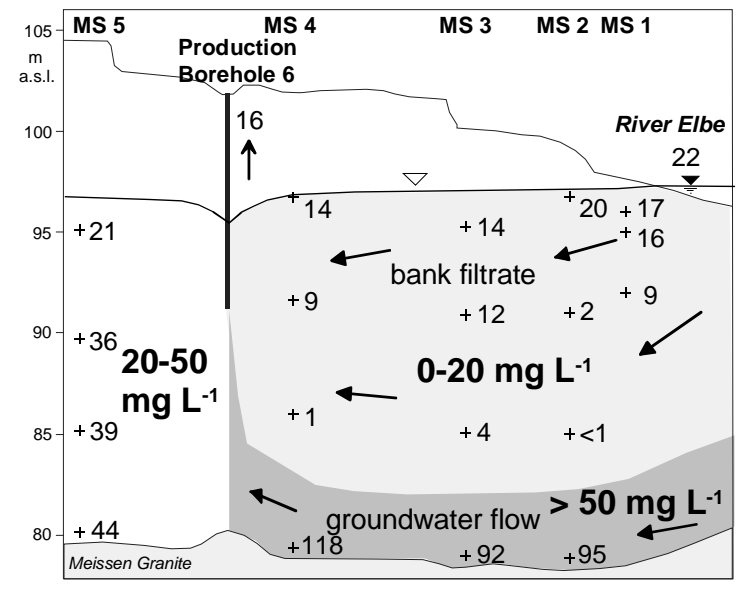

(a)

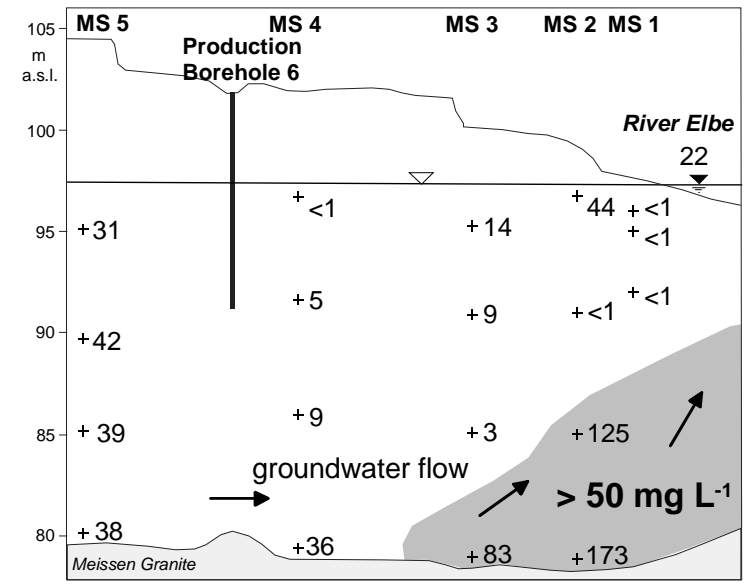

(b)

Figure 7. Nitrate concentrations (mg/L) at observation points along the cross-section. (a) mean values 1993-1995, (b) sampling on 12 May 2001.

Whereas chloride and sulphate concentrations were also high landward of the production well, nitrate concentration was only about $40 \mathrm{mg} / \mathrm{L}$. Only along the right-hand side of the river (looking downstream), the groundwater is highly polluted by nitrate (up to $170 \mathrm{mg} / \mathrm{L}$ ) due to fertilizer applications at vineyards and greenhouses. It was thus realised that the groundwater flows through the lower layer of the aquifer from the right side of the river beneath the river bed towards the production well. In the upper and middle layer of the aquifer, nitrate concentrations were lower than in river water due to denitrification processes along the flow path of bank filtrate.
The indication of groundwater flow beneath the river bed was further supported by results of the determination of dissolved organic carbon (DOC) and ethylenediaminetetraacetate (EDTA). In the lower layer of the aquifer, low DOC and EDTA concentrations were found indicating mixing of groundwater and a small proportion of bank filtrate (Grischek et al., 1994). Low DOC values in this layer also suggested a high proportion of weakly or non-biodegradable organic matter resulting in a carbon limitation of the denitrification rate. 
During the exploitation of full production capacity, the waterworks abstracted in total $0.044 \mathrm{~m}^{3} / \mathrm{s}$ from the wells 6,7 , and 8. Since 1996, water abstraction from these wells has been limited to only a few days per year. A groundwater sampling campaign in 2001 showed that as a consequence the bank filtrate in the aquifer was slowly replaced by groundwater. However, there were still high nitrate concentrations in the lower layer of the aquifer and near the river, indicating a very slow process of replacement and the effects of occasional pumping (Fig. 7b). High sulphate and chloride concentrations, found at sampling points next to river, indicated an up-coning of the groundwater from the lower layer and exfiltration into the river.

The geohydraulic assumptions based on hydrochemical investigations were verified by groundwater flow modelling using Processing Modflow for Windows (Chiang and Kinzelbach, 2001), and transport modelling with MT3D using the finite difference method (Zhen, 1990). The model area extended over $1790 \times 800 \mathrm{~m}^{2}$ and four layers of $5 \mathrm{~m}$ thickness each. The groundwater recharge from the River Elbe is controlled by the piezometric heads in the aquifer, the river water levels along the river course and the hydraulic conductance of the river bed. The horizontal conductivity value was set evenly to $1.4 \times 10^{-3} \mathrm{~m} / \mathrm{s}$. The corresponding vertical hydraulic conductivities were chosen to be an order of magnitude smaller than the horizontal conductivities due to anisotropy (the ratio between horizontal and vertical hydraulic conductivity). This allowed for model validation using results from hydrochemical investigations in the four different layers of the cross-section.

The choice of model boundaries was based on the bedrock geomorphology, piezometric contour maps and results from hydrochemical investigations. Neumann type boundaries were used along groundwater flow lines taken from piezometric contour maps $(\mathrm{Q}=0)$, for groundwater flow into the model calculated from the related recharge areas and recharge rates, and for the three abstraction wells. Groundwater recharge from precipitation was set to $2.2 \mathrm{~L} / \mathrm{s} / \mathrm{km}^{2}$. The river was not included as a fixed head boundary but as a Cauchy boundary with a clogging layer in the river bed of $0.1 \mathrm{~m}$ thickness and a hydraulic conductivity of $1 \times 10^{-5} \mathrm{~m} / \mathrm{s}$.

Water head measurements from two sampling campaigns were used for model calibration. Hydraulic conductivities and proportions of pumped water from the production wells were altered slightly to achieve a better fit of measured and computed piezometric heads. A value of 0.25 for the effective porosity is considered reasonable for the alluvial sediments. The longitudinal dispersivity was estimated from the scale length of the transport phenomenon. Values of $10 \mathrm{~m}$ for the longitudinal dispersivity and of $1 \mathrm{~m}$ for both the horizontal and the vertical transverse dispersivities were defined for the present transport model.

The results from groundwater flow and transport modelling reinforced the theory of groundwater flow beneath the river. Figure 8 shows examples for flow path lines of particles

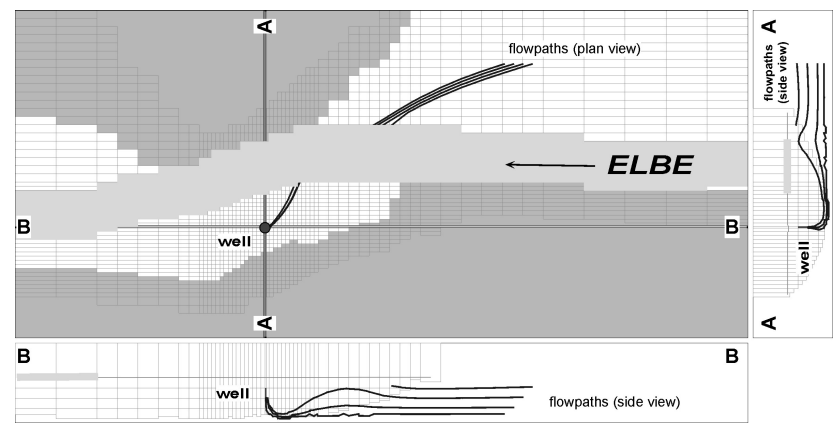

Figure 8. Flow path lines of groundwater from the opposite side of the river.

starting at the right side of the River Elbe in each model layer. Cross-sections A-A and B-B show that only particles starting in the upper layer of the aquifer are flowing into the river. All other particles turn away before they reach the river but flow towards the production well. Thus, high nitrate concentrations in the lower layer of the aquifer between the river and the production well can be explained by groundwater flow from the opposite side of the river.

Due to the small surface and subsurface catchment, the bank filtrate portion is very high. As a function of the clogging intensity in the river bed, the bank filtrate portion varies between 86 and $96 \%$.

Using the groundwater transport model, a time scale of several years for full replenishment of the bank filtrate and groundwater from the opposite side of the river was confirmed by non-steady state calculations. Thus, in 2001 (Fig. 7b), no full replenishment of the nitrate-rich water in the lower layer could be expected.

To investigate the influence of decreasing well abstraction on both the ratios between bank filtrate, landside groundwater and groundwater flow beneath the river bed, four abstraction scenarios were modelled with the MT3D model. Scenario 1 is relevant to the original average abstraction rate of $0.0176 \mathrm{~m}^{3} / \mathrm{s}$ from the well number 6 and contemporarily an abstraction of $0.0142 \mathrm{~m}^{3} / \mathrm{s}$ from both well number 7 and well number 8 . Scenarios 2 to 4 consider only water abstraction from well number 6 with quantities of $0.0176 \mathrm{~m}^{3} / \mathrm{s}$, $0.0088 \mathrm{~m}^{3} / \mathrm{s}$, and $0.0044 \mathrm{~m}^{3} / \mathrm{s}$, respectively.

The closure of wells number 7 and 8 results in $4 \%$ less bank filtrate, thus there is only a little effect on the mixing conditions at well 6 . However, the comparison of all scenarios (Table 5) shows clearly that decreasing water abstraction reduces the bank filtration portion from $85 \%$ (scenario 2) to $73 \%$ (scenario 3) and to $63 \%$ (scenario 4). Consequently, both the portion of landside groundwater and of groundwater flow beneath the river bed increased relative to the total abstraction (Table 5). The total numbers and the relative values for the changes in mixing of various components are shown in Fig. 9. 
Table 5. Mixing conditions at well 6 as function of well abstraction, Meissen-Siebeneichen Waterworks.

\begin{tabular}{lccccc}
\hline Scenario & & 1 & 2 & 3 & 4 \\
\hline total well abstraction & $\mathrm{m}^{3} / \mathrm{s}$ & 0.0176 & 0.0176 & 0.0088 & 0.0044 \\
bank filtrate portion & $\mathrm{m}^{3} / \mathrm{s}$ & 0.0157 & 0.015 & 0.0064 & 0.0028 \\
& $\%$ & 89 & 85 & 73 & 63 \\
Landside portion & $\mathrm{m}^{3} / \mathrm{s}$ & 0.0005 & 0.0009 & 0.0009 & 0.0006 \\
& $\%$ & 3 & 5 & 10 & 14 \\
groundwater flow beneath river & $\mathrm{m}^{3} / \mathrm{s}$ & 0.0014 & 0.0018 & 0.0015 & 0.001 \\
& $\%$ & 8 & 10 & 17 & 22 \\
travel time & days & $30-160$ & $45-210$ & $70-420$ & $210-950$ \\
\hline
\end{tabular}

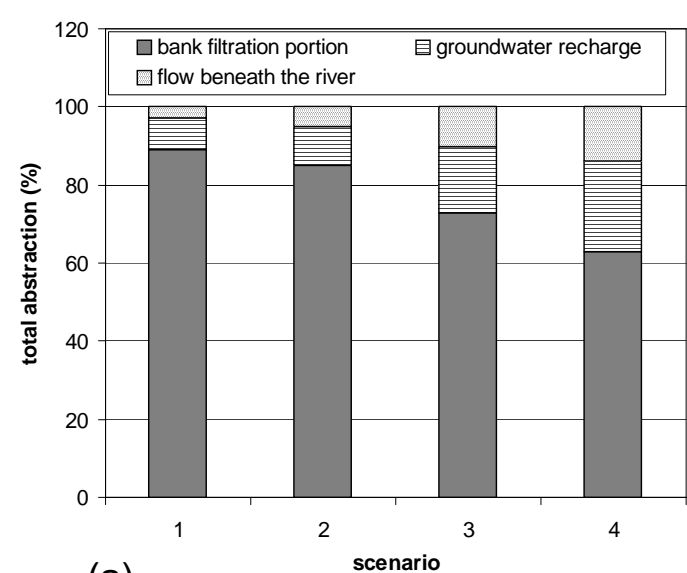

(a)

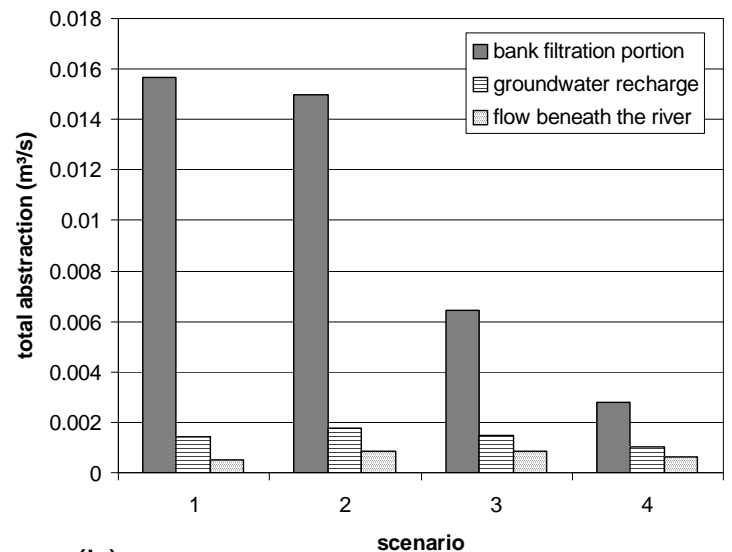

(b)

Figure 9. Total abstraction rates and portions of raw water components. (a) relative portions (b) absolute portions.

Naturally, the travel times between the river and the abstraction well become significantly longer with decreasing abstraction rates. For scenario 1, the bank filtrate travels as a function of the flow paths 30 to 160 days, and for scenario 4 it takes 210 to 950 days (Table 5). These longer travel times as a consequence of less water abstraction mean longer contact times and thus higher removal rates for dissolved organic carbon (Schoenheinz et al., 2004).

\subsection{Generalisation of results based on a hypothetical groundwater flow and transport model}

A hypothetical model covering a recharge area of $2000 \times 1500 \mathrm{~m}^{2}$ and representing an aquifer with two layers was established. The model size and the parameters were chosen from typical conditions for RBF sites in Saxony. To limit the conclusions to the effect of abstraction rates on mixing ratio of landside groundwater and bank filtrate only, full communication between river and aquifer was postulated and no groundwater flow beneath the river bed was considered.

Geohydraulic conditions are documented in Table 6. The hydraulic conductivity was set to $5 \times 10^{-4} \mathrm{~m} / \mathrm{s}$, the hydraulic
Table 6. Geohydraulic conditions for the hypothetical RBF site.

\begin{tabular}{ll}
\hline Condition & Average value \\
\hline aquifer thickness & $50 \mathrm{~m}$ \\
hydraulic conductivity & $5 \times 10^{-4} \mathrm{~m} / \mathrm{s}$ \\
distance between river bank & $200 \mathrm{~m}$ \\
$\begin{array}{l}\text { and abstraction wells } \\
\text { number of wells }\end{array}$ & 4 \\
max. total abstraction rate & $13824 \mathrm{~m}^{3} / \mathrm{d}$ \\
\hline
\end{tabular}

gradient towards the river was set to $0.16 \%$. Boundary conditions are shown in Fig. 10.

Four abstraction wells are located parallel to the river at a distance of $200 \mathrm{~m}$ from the bank. The distance between each of the 4 wells was set to $100 \mathrm{~m}$. The influence of both reduced abstraction rates and the number of abstraction wells on the mixing behaviour between bank filtrate and landside groundwater are of interest. Therefore, 3 scenarios with 4 wells, 2 wells and 1 well were defined (Table 7). 


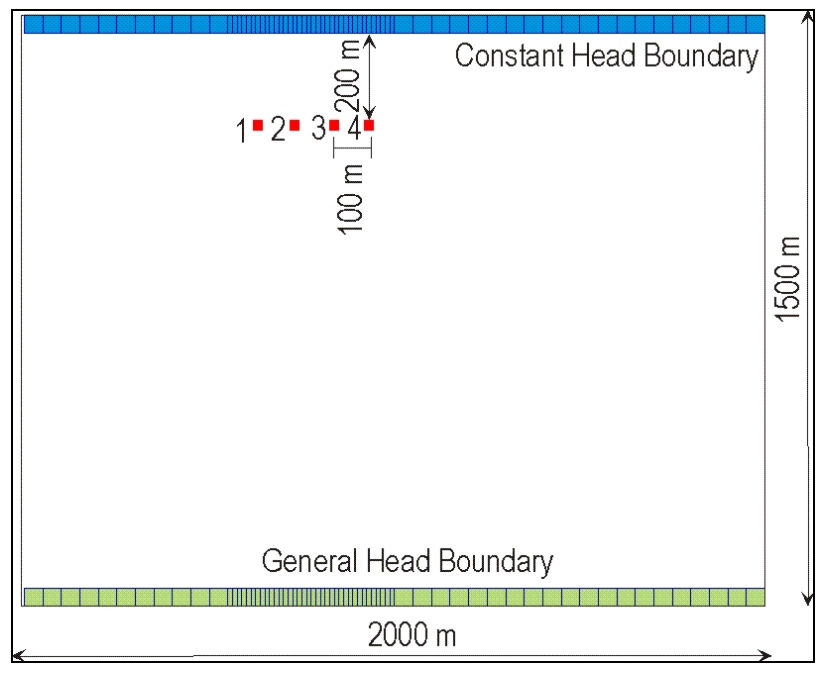

Figure 10. Set-up of hypothetical RBF model.

Assuming a strong decrease in water demand, a subsequent decrease in total water abstraction was modelled. When four wells are in operation, a decrease in total abstraction from $0.16 \mathrm{~m}^{3} / \mathrm{s}$ to $0.08 \mathrm{~m}^{3} / \mathrm{s}$ and $0.04 \mathrm{~m}^{3} / \mathrm{s}$ resulted in a reduction of the portion of bank filtrate from $51 \%$ to $29 \%$ and $6 \%$, respectively (Table 7 ). If the same amount of water were abstracted from only two wells spaced $300 \mathrm{~m}$ apart, the portion of bank filtrate would be slightly lower. If only one well is operated with a high abstraction rate, the portion of bank filtrate would be slightly higher.

To concentrate on selected operation of a lower number of wells could be an advantage in receiving a certain portion of bank filtrate. However, the effect is strongly dependent on the specific geohydraulic site conditions and especially on the distance between the wells and the river bank. Waterworks operating a large number of wells could select wells located nearest to the river bank or within a meander for continuous operation (Grischek et al., 2009, 2003).

\section{Managing bank filtration sites with respect to a fluctuating water demand}

The management of waterworks depends on various limiting factors. Satisfying the fluctuating water demand is of prime importance, although this is often opposed to the preferred continuous operation of wells to ensure stable flow conditions and removal rates. Another important factor is the mixing of river bank filtrate and groundwater to obtain an optimum quality with regard to raw water treatment. At most sites, the main aims of water quality management include achieving the maximum attenuation of organic compounds during aquifer passage and low concentrations of DOC, dissolved iron and nitrate in raw water. At all sites with long flow paths, mixing ratios of bank filtrate and groundwater
Table 7. Impact of well operation on the portion of bank filtrate.

\begin{tabular}{ccccc}
\hline Scenario & $\begin{array}{c}\text { Total } \\
\text { abstraction } \\
\mathrm{m}^{3} / \mathrm{s}\end{array}$ & $\begin{array}{c}\text { Number } \\
\text { of wells }\end{array}$ & $\begin{array}{c}\text { Abstraction from } \\
\text { each well } \\
\mathrm{m}^{3} / \mathrm{s}\end{array}$ & $\begin{array}{c}\text { Portion of } \\
\text { bank filtrate } \\
\%\end{array}$ \\
\hline A & 0.16 & 4 & 0.04 & 51 \\
& & 2 & 0.08 & 50 \\
B & 0.08 & 4 & 0.16 & 52 \\
& & 2 & 0.02 & 29 \\
C & 0.04 & 1 & 0.04 & 28.5 \\
& & 2 & 0.08 & 32 \\
& & 1 & 0.01 & 6 \\
& & 1 & 0.02 & 4 \\
\end{tabular}

were found to be of primary importance to the concentration of DOC, nitrate, sulphate, dissolved iron and manganese in the abstracted raw water.

Figure 11 and Table 8 give an overview of options for management measures at bank filtration sites.

(I) In the short term, optimisation of production well operation is the most promising and probably the most economic way to handle higher portions of landside groundwater and changes in raw water quality due to changing mixing ratios. This entails controlling the flow path length and travel time as well as the mixing by the selection of the most suitable wells from a well field. For that, a detailed investigation of groundwater flow conditions and portions of bank filtrate in the raw water is very important to decisions concerning the most effective water quality management measures.

(II) Knowing the hydrogeologic conditions of an existing bank filtration site, the most convincing way to tackle raw water quality problems related to unfavourable flow or mixing conditions between river and groundwater might be to replace wells. However, during a period of decreasing water demand and lower income of the waterworks, investments necessary to construct new wells - with locations adapted to achieve the principal aims in water pre-treatment - are limited and rare.

(III) Mostly, the frequently occurring seasonal floods in Saxon rivers erode the river bed and limit the clogging. Furthermore, better surface water quality and lower abstraction rates tend to reduce river bed clogging. Consequently, technical measures in the river bed of the River Elbe are not required. For bank filtration sites on rivers with high or increasing river bed clogging due to the organic load or the low water velocity, either frequent river bed cleaning (MartinAlonso, 2003) or the set-up of recharge basins fed by river water are possible solutions. The latter one was practised in Görlitz and Dresden where an increase in water abstraction was required before the 1990s but was not obtainable by bank filtration only. 
Table 8. Management actions in catchments of bank filtration sites.

\begin{tabular}{clll}
\hline & Management action & Actors & Evaluation \\
\hline I & optimisation of well operation & waterworks & short-term, high efficiency \\
II & new well construction (location, depth) & waterworks & expensive \\
III & technical measures in the riverbed & waterworks & continuous measure, expensive \\
IV & changes in land use in the catchment & politics, farmers, waterworks & long-term measure \\
\hline
\end{tabular}

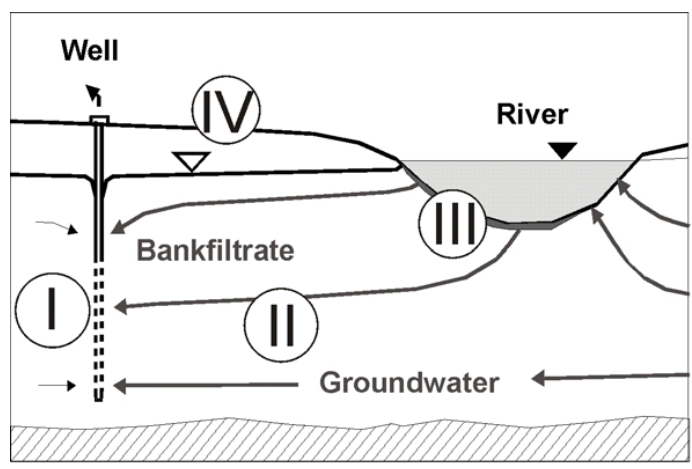

Figure 11. Options for managing river bank filtration in quantity and quality.

(IV) Collaboration with farmers in the catchment area, agreements on compensation payments to limit the application of fertilizers (especially $\mathrm{N}$ ) and pesticides or buying the land are appropriate measures on a long term basis to reduce nitrate, sulphate and pesticide concentrations in landside groundwater. Such measures have been practised with different intensities and varying degrees of success. They may not be successful in balancing the higher nitrate and sulphate concentration of pumped raw water if the portion of landside water is increasing due to lower water abstraction.

\section{Summary}

Bank filtration sites in Germany have been designed decades ago to replace direct abstraction of polluted surface water. Whereas from the 1970s to the 1980s, river water quality and removal of organic pollutants was the major concern in management of bank filtration sites, the situation has changed since 1990. The ongoing decrease in water demand in many regions in Germany, especially in Saxony, leads to lower portions of bank filtrate in the abstracted raw water. Landside groundwater quality becomes more important for the subsequent treatment for drinking water production. At some sites nitrate concentrations greater than $80 \mathrm{mg} / \mathrm{L}$ and sulphate concentrations greater than $300 \mathrm{mg} / \mathrm{L}$ in landside groundwater demand specific mixing ratios between bank filtrate and groundwater in the aquifer to prevent otherwise neces- sary treatment to remove nitrate and/or sulphate. The identification and determination of flow path indicators require not only the knowledge of hydrogeological conditions but also an integrated consideration of land and water use in the catchment of the bank filtration sites.

As a function of the river bed conditions, the land use on the opposite side of the river is also important because groundwater flow beneath the river towards the wells is not a priori negligible. At sites with high organic loads in the river water and less erosive conditions, clogging may enhance groundwater flow beneath the river bed. Of course, with a decrease in water abstraction the clogging induced by the operation of wells becomes less important due to lower infiltration rates and thus lower input of particles per square meter of river bed. However, even for rivers without any clogging of the bed, the anisotropy of the aquifer can result in groundwater flow beneath the river. Under such conditions, not only the catchment protection on the bank where the well field is located but also the land use and thus the groundwater quality on the far bank might play an important role.

Generally, it can be concluded that lower abstraction rates decrease the bank filtration portion and increase the influence of landside groundwater on the raw water quality. Thus, optimisation of well operation to cover the lower mean demand and the remaining peak demand becomes a key issue in management of bank filtration sites.

Under other hydrogeological or other socio-political conditions as discussed herein, the flow conditions such as mixing behaviour, groundwater flow beneath the river and travel times should be investigated by groundwater flow modelling prior to any planning, construction or optimisation of bank filtration sites.

Acknowledgements. The authors are grateful to the Ministry for Science and Art, Saxony, for financial support (grant no. 475316002512007), and to Mr. Deike (waterworks Görlitz), Mrs. Böhm (OEWA GmbH) and Mr. Fischer (DREWAG $\mathrm{GmbH}$ ) for professional support.

Edited by: B. Heijman 


\section{References}

BDEW: German Federal Association of Energy and Water Resources Management, www.bdew.de, last access: 1 July 2009 (in German).

City of Dresden: Drinking Water Abstraction, www.dresden.de, last access: 1 July 2009.

Chiang, W.-H. and Kinzelbach, W.: 3D-Groundwater Modeling with PMWIN, Springer, Berlin, Heidelberg, New York, 2001.

FSA: Public water supply by water source, Federal Statistical Authority Germany, www.destatsi.de, last access: 1 July 2009 (in German).

Grischek, T. and Ray, C.: Bank filtration as managed surface groundwater interaction, Int. J. Water, 5(2), 125-139, 2009.

Grischek, T., Schoenheinz, D., and Ray, C.: Siting and design issues for riverbank filtration schemes, in: Riverbank Filtration: Improving Source-Water Quality, edited by: Ray, C., Melin, G., and Linsky, R., Kluwer Academic Publ., 291-302, 2003.

Grischek, T., Schoenheinz, D., and Nestler, W.: Unexpected groundwater flow beneath the River Elbe at the bank filtration site Meissen, Germany, in: Water resources and environment research, edited by: Schmitz, G. H., ICWRER 2002, 1, 116-120, 2002.
Grischek, T., Nestler, W., Dehnert, J., and Neitzel, P.: Groundwater/river interaction in the Elbe River basin in Saxony, in: Ground Water Ecology, edited by: Stanford, J. A. and Vallett, H. M., American Water Resources Association, Herndon, 309-318, 1994.

Hillenbrand, T. and Schleich, J.: Determinants of water demand in Germany, energie wasser-praxis, 6, 38-42, 2009 (in German).

Kühn, W. and Müller, U. (Eds.): Export oriented research and development in the field of water supply and treatment, part drinking water, DVGW, Germany, 2005 (in German).

Martin-Alonso, J.: Combined use of surface water and groundwater for drinking-water production in the Barcelona metropolitan area, Proc. 2nd Int. Riverbank Filtration Conf., 16-19.09.2003, Cincinnati, 217-222, 2003.

Schoenheinz, D., Grischek, T., and Worch, E.: Investigations on temperature effects on the DOC degradation during river bank filtration, Proc. Annual Conference of the Water Chemistry Society, 17.-19.05.2004, Bad Saarow, 150-154, 2004 (in German).

Schwanke, M.: Groundwater flow modelling and investigations into the development of the water balance at waterworks Göttwitz, Master thesis, University of Applied Sciences Dresden, Faculty of Civil Engineering/Architecture, 2008 (in German).

Zhen, C.: MT3D, a modular three-dimensional transport model, S.S. Papadopulos and Associates, Inc., Rockville, MD, 1990. 